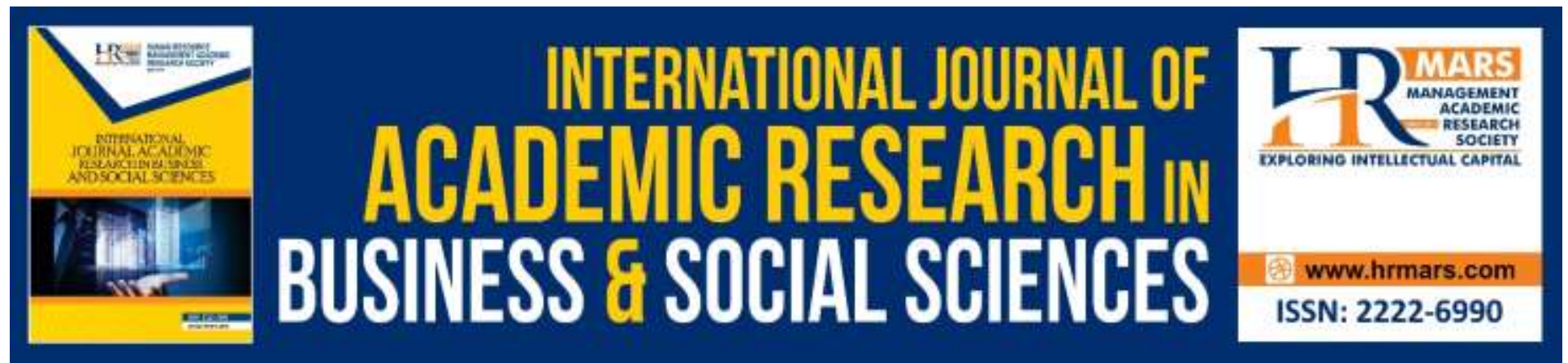

\title{
Students' Thesis Writing Skills in Postgraduate Studies
}

\section{Teoh Sian Hoon, Geethanjali Narayanan, Gurnam Kaur Sidhu, Lim Peck} Choo, Chan Yuen Fook, Priyadarshini Muthukrishnan

To Link this Article: http://dx.doi.org/10.6007/IJARBSS/v9-i13/7001

DOI: 10.6007/IJARBSS/v9-i13/7001

Received: 24 September 2019, Revised: 27 October 2019, Accepted: 06 November 2019

Published Online: 28 November 2019

In-Text Citation: (Hoon et al., 2019)

To Cite this Article: Hoon, T. S., Narayanan, G., Sidhu, G. K., Choo, L. P., Fook, C. Y., \& Priyadarshini Muthukrishnan. (2019). Students' Thesis Writing Skills in Postgraduate Studies. International Journal of Academic Research in Business and Social Sciences, 9(13), 514-524.

Copyright: (C) 2019 The Author(s)

Published by Human Resource Management Academic Research Society (www.hrmars.com)

This article is published under the Creative Commons Attribution (CC BY 4.0) license. Anyone may reproduce, distribute, translate and create derivative works of this article (for both commercial and non-commercial purposes), subject to full attribution to the original publication and authors. The full terms of this license may be seen at: http://creativecommons.org/licences/by/4.0/legalcode

Special Issue: Revolutionizing Education: Challenges, Innovation, Collaboration, 2019, Pg. 514 - 524 http://hrmars.com/index.php/pages/detail/IJARBSS JOURNAL HOMEPAGE

Full Terms \& Conditions of access and use can be found at http://hrmars.com/index.php/pages/detail/publication-ethics 


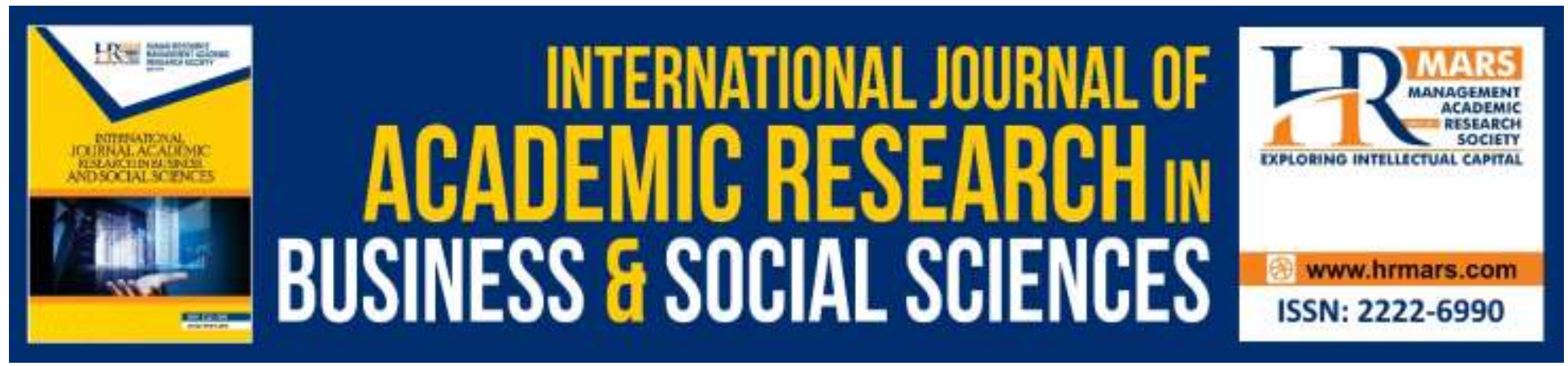

\title{
Students' Thesis Writing Skills in Postgraduate Studies
}

\section{Teoh Sian Hoon ${ }^{1}$, Geethanjali Narayanan², Gurnam Kaur Sidhu ${ }^{3}$, Lim Peck $\mathrm{Choo}^{4}$, Chan Yuen Fook ${ }^{5}$, Priyadarshini Muthukrishnan ${ }^{6}$ \\ 1,2, 5 Faculty of Education, Universiti Teknologi MARA Selangor, 42300 Puncak Alam, Selangor, Malaysia, ${ }^{3,6}$ Faculty of Education, SEGi University, Kota Damansara, 47810 Petaling Jaya, Selangor, Malaysia, ${ }^{4}$ Academy of Language Studies, Universiti Teknologi MARA, 40000 Shah \\ Alam, Selangor, Malaysia}

\begin{abstract}
This study explored a new direction relating to research supervision. A few important students' skills were identified and related to the needs of hybrid supervision. Specifically, this study investigated the influence of these skills during their postgraduate studies. This study employed the descriptive survey research design. A total of 191 postgraduate students from universities in Klang Valley Malaysia participated in this study. The findings revealed that postgraduate students have perceived their abilities or skills in completing their thesis or dissertation averagely shown moderate level of the overall skills (mean=3.66 over maximum value of 5.00). Among the skills, personal skills and critical reading skills are a bit higher than the other skills. These skills are emphasized in current educational direction of $21^{\text {st }}$ century skills as well as a plan in Education 4.0. Hence, this study has put forward that there is room for improvement for personal skills in postgraduate study. Focusing on this personal skill, more enhancement on other skills such as reading and writing skills can be easily achieved with current technology. Since, postgraduate studies involves supervision, hence it is suggested that a system called Hybrid Supervision (HS) to be implemented. HS takes into consideration the current required conditions to enhance students' inner factors for thesis completion. For more innovative development, it was also suggested that students need to be involved themselves in online application (Apps) for the process of postgraduate studies. Hence, the findings in this study has supported educational direction to produce individual with multiple of skills.
\end{abstract}

Keywords: Students' Factors, Skills of Completing Postgraduate Study, Hybrid Supervision, Graduate on Time.

\section{Introduction}

Postgraduate (hereafter PG) students' ability to complete their studies on time has become one of the main concerns of universities globally. Universities place a lot of attention on graduating 
on time (hereafter GOT) because it is one of the criteria for university ranking. When a student embarks on PG study, his/her aim would be to graduate on time. GOT is defined in Malaysia as completing and graduating within seven semesters, plus one year for assessments (MyRA2). However, there are many factors that contribute towards GOT. In a study conducted by Jiranek (2010), the main factors are: (1) student qualities and personal situation, (2) research facilities and resources and (3) supervisory and scholarly environment. PG students are expected to be independent workers. However, due to the lack of confidence and limited knowledge, they seek for approval from the supervisors.

This paper is part of a bigger study, a Fundamental Research Grant Scheme (FRGS), in which perceptions of PG students and supervisors were done separately with several factors for each. When PG students are asked about their perception towards their studies, tapping on the inner factors. They have different perceptions towards their PG studies. When PG supervisors were asked about their supervisees, there were also mixed answers. On the whole, the conclusion drawn from the study is that PG students felt that they need to have certain skills and would like to learn or enhance that skill while embarking on thier PG journey. This was similar to what was suggested by supervisors that PG students need more training.

It is a norm in PG supervision, students' problems related to GOT is tackled by monitoring and providing training to the students. As such, students need to possess critical reading and writing skills. Besides this, they also need to familiarize themselves with research skills. All of these would be helpful to conduct their research not only independently, but also confidently. As they progress from one semester to another, their research skills will keep improving, regardless whether through discovery or guidance from supervisors through seminars or workshops. Many supervisors opt to introduce technology related assistance like educational Apps for skill improvement. Thus, this paper attempts to dwell into a strategy called Hybrid Supervision, which is to help PG students to develop, refine and enhance their skills related to their PG studies. There are many strategies used to developed skills among students (Tercanlioglu, 2004; Khalid, Islam \& Ahmed, 2019). Among the strategies, the hybrid method has been proven to motivate students' learning (Hall \& Villareal, 2015). Hybrid learning or blended learning is commonly applied for any courses with online communication system. Students who work within this environment show personal skills in monitoring and managing themselves since these skills are required for them to be active in this system. PG students' engagement is commonly observed through online system. Currently, many thesis supervisors make use of online facilities to communicate with their supervisees. Nevertheless, not all supervisees are willing to fully commit in this virtual learning environment. It was revealed that students who are keen to read inputs provided and reply to any feedback in communication are enthusiastically engaged in developing research skills and hence competent to carry out thesis work (Dixson, 2015; Alzgool, 2019; Muhammad, Saoula, Issa \& Ahmed, 2019).

As Malaysia heads towards the status of a developed country by 2020, there is a need to develop a pool of successful innovative quality scholars in a flexible learning environment as highlighted in Education 4.0. Elements in Education 4.0 should to be enhanced to achieve the above purpose. Supervisors need to understand that these elements will help the students to develop many required learning skills and hence achieve GOT. Along the way of including flexible learning 
elements, pedagogical content knowledge (from many resources such as supervisors, books etc), andragogy (students are guided and motivated), heutagogy (students take more responsibility), peerology (students work collaboratively with peers) with cyberlogical environment (assisted with internet of things) are applied in the Hybrid Supervision Model.

Jones and Matlay (2014) highlighted that several pertinent ideas surrounding pedagogical content knowledge and heutagogy and academagogy should be brought to the attention of academics/researchers involved in the design, development and delivery of enterprise education. Pedagogy focuses quality content knowledge (Garnette, 2013; Blaschke \& Hase, 2016; Winter, 2013), while Andragogy focuses learning process which moves on to motivating and negotiating the students (Garnette, 2013; Blaschke \& Hase, 2016; Smith, 2010). In addition, Heutagogy emphasizes on students' responsibility in learning (Garnette, 2013; Blaschke \& Hase, 2016; Narayan \& Herrington, 2014), and Cybergogy provides the supportive learning environment (Carrier \& Moulds, 2003). Based on the literature and the preliminary research, a model was created (Figure 1).

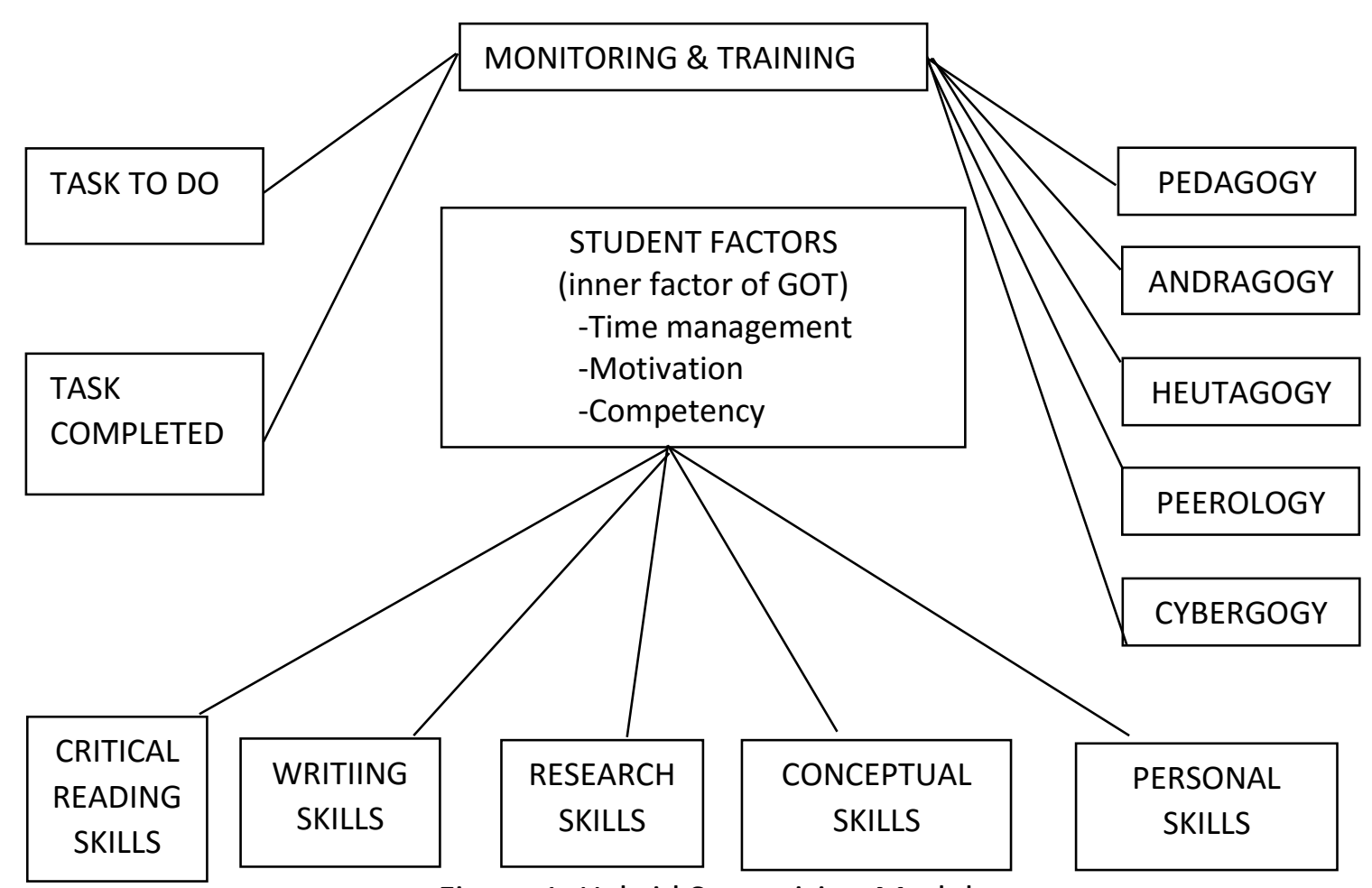

Figure 1. Hybrid Supervision Model

Figure 1 highlights the important skills used in writing thesis. Students need to develop critical reading skills, writing skills, research skills, conceptual skills and personal skills to get themselves confident in writing thesis. The skills which complement with guidance is contributed in a form of monitoring and training. The process of monitoring and training is accompanied with elements of pedagogy, andragogy, heutagogy, peerology and cyberlogy within the task under completion. This paper focuses on the students' inner factors for thesis completion: critical reading, writing, research, conceptual and personal skills. 


\section{Methodology}

In this study, the population involved all postgraduate students from two universities in the area of Klang Valley, Malaysia. Block random sampling was used to select four faculties from the two universities. The questionnaire was sent to all postgraduate students from the four selected faculties. A total of 191 students participated and answered the questionnaire. Table 1 shows the distribution of the participants.

\begin{tabular}{|c|c|c|c|c|c|}
\hline & & $\begin{array}{c}\text { Frequenc } \\
\mathrm{y}\end{array}$ & Percent & $\begin{array}{c}\text { Valid } \\
\text { Percent }\end{array}$ & $\begin{array}{c}\text { Cumulative } \\
\text { Percent }\end{array}$ \\
\hline & Male & 49 & 25.7 & 25.7 & 25.7 \\
\hline \multirow[t]{2}{*}{ Valid } & Female & 142 & 74.3 & 74.3 & 100.0 \\
\hline & Total & 191 & 100.0 & 100.0 & \\
\hline
\end{tabular}

Overall, Table 2 shows there are 64 students who enrolled in coursework/mixed mode for a master programme, 57 students enrolled in full research master programme and 70 registered for a PhD programme.

Table 2 Programme

\begin{tabular}{lcc}
\hline & Frequency & Percent \\
\hline Masters (Coursework/ mixed mode) & 64 & 33.6 \\
Master (Full Research) & 57 & 29.8 \\
PhD (Full research) & 70 & 36.6 \\
Total & 191 & 100 \\
\hline
\end{tabular}

Table 3 indicates majority of the students are in writing proposal stage (31.9\%). The rest of the students are in literature review stage (12.6\%), data collection (11.5\%), data analysis (15.2\%), reporting findings (12\%), writing for viva $(7.3 \%)$, others $(9.4 \%)$.

Table 3 Stages of the postgraduate students' study

\begin{tabular}{|l|l|l|l|l|l|}
\hline \multicolumn{2}{|c|}{} & Frequency & Percent & Valid Percent & $\begin{array}{l}\text { Cumulative } \\
\text { Percent }\end{array}$ \\
\hline \multirow{8}{*}{ Valid } & Writing of proposal & 61 & 31.9 & 31.9 & 31.9 \\
\cline { 2 - 6 } & Literature review & 24 & 12.6 & 12.6 & 44.5 \\
\cline { 2 - 6 } & Data collection & 22 & 11.5 & 11.5 & 56.0 \\
\cline { 2 - 6 } & Data analysis & 29 & 15.2 & 15.2 & 71.2 \\
\cline { 2 - 6 } & Reporting findings & 23 & 12.0 & 12.0 & 83.2 \\
\cline { 2 - 6 } & Writing for viva & 14 & 7.3 & 7.3 & 90.6 \\
\cline { 2 - 6 } & Others & 18 & 9.4 & 9.4 & 100.0 \\
\cline { 2 - 6 } & Total & 191 & 100.0 & 100.0 & \\
\hline
\end{tabular}

The instrument used was a questionnaire that was adopted and adapted from Sidhu's et al.(2014) study. The questionnaire consists of 32 items representing student factor for thesis completion. A reliability test was carried out. The Cronbach's A;pha value of the reliability for 32 items is 
0.976..This study employed a descriptive survey research design to collect data and analyse descriptively and inferentially. In the analysis, descriptive statistics was applied to answer the research question one on the students' perception of their skill levels in completing their studies. Secondly, the focus was on the comparation of the skill levels among the groups in different stages of study (from writing a proposal to completing their study). The distribution of data was observed on the overall skewness. It shows that the skewness is close to zero namely 0.043 . Thus, the data closely distributed normally.

\section{Findings}

The findings are presented based on the two research questions as stated in the each part of analyses as below.

Research Question One: What are the postgraduate students' level of skills of completing a thesis?

The results (Table 4) of students' abilities in writing thesis were observed from the perspectives of five skills (critical reading skill, writing skill, research skill, conceptual skill and personal skill). Based on a scale of 1 to 5 , the students rated their skills averagely with mean of 3.66 with critical reading and personal skills (both mean=3.80) having the highest mean but the writing (mean=3.54) and research (mean=3.57) skills were rated lower. The standard deviations ranged from 0.61 to 0.72 .

Table 4. Descriptive Statistics

\begin{tabular}{lccccc}
\hline & N & Minimum & Maximum & Mean & Std. Deviation \\
\hline Student Critical reading skill & 191 & 2.00 & 5.00 & 3.80 & .62 \\
Student writing skill & 191 & 2.00 & 5.00 & 3.54 & .72 \\
Student Research Skill & 191 & 1.71 & 5.00 & 3.57 & .68 \\
Student Conceptual skill & 191 & 1.67 & 5.00 & 3.61 & .69 \\
Student Personal Skill & 191 & 2.00 & 5.00 & 3.80 & .68 \\
Overall & 191 & 2.00 & 5.00 & 3.66 & .61 \\
Valid N (listwise) & 191 & & & & \\
\hline
\end{tabular}

Further analysis was conducted to investigate on their level of skills for the different stages of study. The stages include writing proposal, literature review, data collection, data analysis, reporting findings and writing for viva. The results (Table 5) show that generally, for all the skills in this observation, the students in the early stage of study (writing of proposal stage) rated their skills a bit lower than students who are in an advanced level their study (reporting findings and writing for viva). For example, rating for skill of critical reading (the first skill in the table), writing proposal stage was rated a bit lower (mean =3.67) than the higher stages in literature review, data collection, data analysis, reporting findings and writing for viva with means 3.72, 3.76. 3.84, 3.91 and 4.10 respectively. Nevertheless, all the skills (except for critical reading and personal skills) were rated lower in stage of writing for viva compared to the stage before reporting the findings. On the other hand, there is a pattern of increasing skill level in stages among all the skills but the pattern was not shown in personal skill. Hence, descriptively, students' skills (except critical reading) were rated higher for the increasing stages of thesis writing except writing for viva and data analysis (for writing and personal skills). The findings revealed that descriptively 
the level of skills become higher when the students move to a higher stage of writing, but generally their level showed dropping when they progressed to writing for viva. The findings revealed that generally the students in writing for viva stage rated all their skills lower (except the critical reading skill). Basically, students' skills become better when they move to the next stage of completing the thesis, but students who in the stage of writing viva might have lost confidence to rate their level of skills higher than before. They rated their skills they possess lower than the earlier stages.

Table 5 Skills level in different stages

N Mean Std. Deviation

\begin{tabular}{|c|c|c|c|c|}
\hline \multirow{8}{*}{$\begin{array}{l}\text { Student Critical reading } \\
\text { skill }\end{array}$} & Writing of proposal & 61 & 3.67 & .63 \\
\hline & Literature review & 24 & 3.72 & .62 \\
\hline & Data collection & 22 & 3.76 & .58 \\
\hline & Data analysis & 29 & 3.84 & .66 \\
\hline & Reporting findings & 23 & 3.91 & .64 \\
\hline & Writing for viva & 14 & 4.10 & .58 \\
\hline & Others & 18 & 3.94 & .51 \\
\hline & Total & 191 & 3.80 & .62 \\
\hline \multirow{8}{*}{ Student writing skill } & Writing of proposal & 61 & 3.4098 & .74 \\
\hline & Literature review & 24 & 3.5417 & .74 \\
\hline & Data collection & 22 & 3.5833 & .67 \\
\hline & Data analysis & 29 & 3.3851 & .86 \\
\hline & Reporting findings & 23 & 3.8116 & .60 \\
\hline & Writing for viva & 14 & 3.6190 & .64 \\
\hline & Others & 18 & 3.7315 & .60 \\
\hline & Total & 191 & 3.5366 & .72 \\
\hline \multirow{8}{*}{ Student Research Skill } & Writing of proposal & 61 & 3.4333 & .75 \\
\hline & Literature review & 24 & 3.4345 & .70 \\
\hline & Data collection & 22 & 3.4870 & .58 \\
\hline & Data analysis & 29 & 3.5714 & .74 \\
\hline & Reporting findings & 23 & 3.8137 & .59 \\
\hline & Writing for viva & 14 & 3.7857 & .55 \\
\hline & Others & 18 & 3.7857 & .53 \\
\hline & Total & 191 & 3.5654 & .68 \\
\hline \multirow{7}{*}{ Student Conceptual skill } & Writing of proposal & 61 & 3.5000 & .66 \\
\hline & Literature review & 24 & 3.5833 & .78 \\
\hline & Data collection & 22 & 3.5000 & .72 \\
\hline & Data analysis & 29 & 3.5345 & .85 \\
\hline & Reporting findings & 23 & 3.8696 & .58 \\
\hline & Writing for viva & 14 & 3.6905 & .55 \\
\hline & Others & 18 & 3.8519 & .51 \\
\hline
\end{tabular}


INTERNATIONAL JOURNAL OF ACADEMIC RESEARCH IN BUSINESS AND SOCIAL SCIENCES

Vol. 9, No. 13, Special Issue: Revolutionizing Education: Challenges, Innovation, Collaboration., 2019, E-ISSN: 2222-6990 @ 2019 HRMARS

\begin{tabular}{llrrr} 
& Total & 191 & 3.6073 & .69 \\
\cline { 2 - 5 } Student Personal Skill & Lriting of proposal & 61 & 3.6373 & .60 \\
& Literature review & 24 & 3.7552 & .79 \\
& Data collection & 22 & 3.6705 & .64 \\
& Data analysis & 29 & 3.6293 & .87 \\
& Reporting findings & 23 & 4.0761 & .53 \\
& Writing for viva & 14 & 4.1696 & .55 \\
& Others & 18 & 4.1875 & .44 \\
\cline { 2 - 4 } Student Factor & Total & 191 & 3.7984 & .68 \\
& Writing of proposal & 61 & 3.5292 & .59 \\
& Literature review & 24 & 3.6068 & .67 \\
& Data collection & 22 & 3.5966 & .56 \\
& Data analysis & 29 & 3.5862 & .76 \\
& Reporting findings & 23 & 3.9049 & .53 \\
& Writing for viva & 14 & 3.8817 & .48 \\
& Others & 18 & 3.9132 & .41 \\
& Total & 191 & 3.6626 & .61 \\
\hline
\end{tabular}

Research question 2: Is there any difference in the skill levels among the students in different stage of study?

Table 6 shows that:

(1) There is no significant different in the skills (all except personal skill) among the students in different stage of study since the $p=$ values $>0.05$.

(2) There is no significant different in the skills (all except personal skill) among the students in different stage of study since the $p=$ values $<0.05, F=3.569$.

(3) As overall, the result shows that overall there is a mild significant in the skills among the different stage of study, the $p$-value close to 0.05 . 
INTERNATIONAL JOURNAL OF ACADEMIC RESEARCH IN BUSINESS AND SOCIAL SCIENCES

Vol. 9, No. 13, Special Issue: Revolutionizing Education: Challenges, Innovation, Collaboration., 2019, E-ISSN: 2222-6990 @ 2019 HRMARS

\begin{tabular}{|c|c|c|c|c|c|c|}
\hline \multicolumn{7}{|l|}{ Table 6. ANOVA } \\
\hline & & $\begin{array}{l}\text { Sum of } \\
\text { Squares }\end{array}$ & df & Mean Square & $\mathrm{F}$ & Sig. \\
\hline \multirow{3}{*}{$\begin{array}{l}\text { Student Critical reading } \\
\text { skill }\end{array}$} & Between Groups & 3.224 & 6 & .537 & 1.423 & .208 \\
\hline & Within Groups & 69.456 & 184 & .377 & & \\
\hline & Total & 72.680 & 190 & & & \\
\hline \multirow{3}{*}{ Student writing skill } & Between Groups & 4.213 & 6 & .702 & 1.354 & .236 \\
\hline & Within Groups & 95.419 & 184 & .519 & & \\
\hline & Total & 99.632 & 190 & & & \\
\hline \multirow{3}{*}{ Student Research Skill } & Between Groups & 4.583 & 6 & & 1.687 & .126 \\
\hline & Within Groups & 83.328 & 184 & .453 & & \\
\hline & Total & 87.912 & 190 & & & \\
\hline \multirow{3}{*}{ Student Conceptual skill } & Between Groups & 3.879 & 6 & .646 & 1.369 & .229 \\
\hline & Within Groups & 86.893 & 184 & .472 & & \\
\hline & Total & 90.772 & 190 & & & \\
\hline \multirow{3}{*}{ Student Personal Skill } & Between Groups & 9.246 & 6 & 1.541 & 3.569 & .002 \\
\hline & Within Groups & 79.432 & 184 & .432 & & \\
\hline & Total & 88.677 & 190 & & & \\
\hline \multirow{3}{*}{ Student Factor } & Between Groups & 4.578 & 6 & .763 & 2.138 & .051 \\
\hline & Within Groups & 65.675 & 184 & .357 & & \\
\hline & Total & 70.253 & 190 & & & \\
\hline
\end{tabular}

This finding shows that the students' personal skills are not stable among the students in stage of 'writing for viva' which is comparatively higher than students in other stages. Namely, without considering stage of 'other', students who were in stage of 'writing for viva' has the personal skill at level 4.1696. These findings revealed that students in higher level of stage of writing (example: writing for viva) have a better personal skill.

\section{Discussion and Conclusion}

In this study, there are three main findings. The discussion for the main findings are presented as below:

(a) the PG students perceived their abilities or skills in completing their thesis or dissertation averagely with a moderate level of the overall skills. Among the skills, the personal and critical reading skills are a slightly higher than the other skills. The result has provided the current learning scenario that students like to communicate online, they learn and gain a lot of knowledge via online. It directly displays their preference of learning in flexible manner. Their communication produces a strong sense of community among students when they are able to contacting each other or sharing their ideas (Ovai \& Jordan, 2004). A study also describes that learning in hybrid environment is effective compared to traditional learning because the advantages in learning engagement and interaction value (Dziuban, Moskal \& Hartman, 2005). Since personal skills (monitoring, time management) are always rated important (Nabi \& Bagley, 1999), in addition these skills may be used to enhance other postgraduate study skills, hence it is significant to apply personal skills in the application of hybrid environment for the matter of 
supervision. The hybrid environment may prepare students to be active in developing their skills and effort to complete their studies. The availability of this environment enables them to share ideas, discuss openly and getting more critical inputs based on students' feedback. This kind of similar environment has been introduced recently in promoting peer-support thesis learning group (Kaakinen, Suhonen, Lutovac \& Kaasila, 2017). More importantly, postgraduate students need to develop personal skills for more social interaction.

(b) the PG students' abilities in 'personal skills' showed significant difference among the students in different stages. This finding revealed that students' personal skills were developed when they are in a more advanced stage like 'writing for viva'. The students have gone through a lot of experience and they learned from the process of writing from proposal to drafting the thesis. Thesis writing takes a long time to be completed. Students are capable of developing their personal skills such as self-management. This skill is emphasized in current educational direction of $21^{\text {st }}$ century skills as well as a plan in Education 4.0. Hence, this study has put forward that there is room for improvement for personal skills in PG study. For more innovative development, it was also suggested that students need to be involved themselves in online application for the process of postgraduate studies from the beginning of their first semester. Hence, the finding in this study has supported educational direction to produce individual with multiple of skills.

(c) This study revealed that there is no significant difference in other skills (namely reading, writing, conceptual, research). This indicates that the students own similarities in their skills. The more advanced level of PG students do not show higher abilities in these skills. Hence, it may cause the final stage students (thesis writing stage) do not show confidence in completing their thesis (their level of means are not significantly higher than other stage students). Hence, the students need more help for skills enhancement from beginning stage of study. This is where the Hybrid Supervision model is utilized. Whatever skills that are thought necessary for the PG students to complete their studies are then suggested via workshops or seminars.

\section{Conclusion}

From these findings, it can be concluded that PG students are open to learning and enhancing their skills in order to GOT. The hybrid supervision model develops PG students' inner factors of completing a thesis. The focused factors are time management skill, motivational factor and competency in completing a thesis (focusing on reading skill, writing skill, research skill and conceptual skill). The important actions taken to enhance the above factors would focus on monitoring and training towards completion of thesis. The monitoring part is taken under task to do (assigned task by supervisor) and training for a few important aspects in Education 4.0 (pedagogy, andragogy, heutagogy, peerology and cybergogy). Therefore, the Hybrid Supervision is done with supervisors giving advice and guidance to lead to thesis writing, coupled with the students' inner factors, maintaining of their personal skills of monitoring themselves and throughout the proses of writing thesis. 


\section{References}

Adams, M. J. (1994). Beginning to read: Thinking and learning about print. MIT press.

Alzgool, M. (2019). Nexus between Green HRM and Green Management towards Fostering Green Values. Management Science Letters, 9(12), 2073-2082.

Dixson, M. D. (2015). Measuring Student Engagement in the Online Course: The Online Student Engagement Scale (OSE). Online Learning, 19(4), n4.

Dziuban, C., Moskal, P., \& Hartman, J. (2005). Higher education, blended learning, and the generations: Knowledge is power: No more. Elements of quality online education: Engaging communities. Needham, MA: Sloan Center for Online Education, 88-89.

Hadi, N. U., \& Muhammad, B. (2017). Role of Supervisor in the Performance of Postgraduate Research Students. Journal of Research \& Reflections in Education (JRRE), 11(2).

Hall, S., and Villareal, D. (2015). The hybrid advantage: graduate student perspectives of hybrid education courses. International Journal of Teaching and Learning in Higher Education, 27(1), 69-80.

Jiranek, V. (2010). Potential Predictors of Timely Completion among Dissertation Research Students at an Australian Faculty of Sciences. International Journal of Doctoral Studies, 5, 1-13.

Kaakinen, P., Suhonen, M., Lutovac, S., \& Kaasila, R. (2017). Students experiences of peersupport during a Master's thesis process. Clinical Nursing Studies, 5(1), 22.

Khalid, N., Islam, D. M. Z., \& Ahmed, M. R. M. (2019). Sentrepreneurial Training and Organizational Performance: Implications for Future. Humanities \& Social Sciences Reviews, 7(2), 590-593.

Muhammad, K., Saoula, O., Issa, M., \& Ahmed, U. (2019). Contract Management and Performance Characteristics: An Empirical and Managerial Implication for Indonesia. Management Science Letters, 9(8), 1289-1298.

Nabi, G. R., \& Bagley, D. (1999). Graduates' perceptions of transferable personal skills and future career preparation in the UK. Education + Training, 41(4), 184-193.

Ovai, A. P., \& Jordan, H. (2004). Blended learning and sense of community: A comparative analysis with traditional and fully online graduate courses. The International Review of Research in Open and Distributed Learning, 5(2).

Parker, R. (2012). Skill development in graduate education. Molecular cell, 46(4), 377-381.

Sidhu, G. K., Kaur, S., Fook, C. Y., \& Yunus, F. W. (2014), Postgraduate supervision: Comparing student perspectives from Malaysia and the United Kingdom. Procedia - Social and Behavioural Sciences 123, 151-159. https://doi.org/10.1016/j.sbspro.2014.01.1409

Tercanlioglu, L. (2004). Postgraduate Students' Use of Reading Strategies in L1 and ESL Contexts: Links to Success. International Education Journal, 5(4), 562-570. 